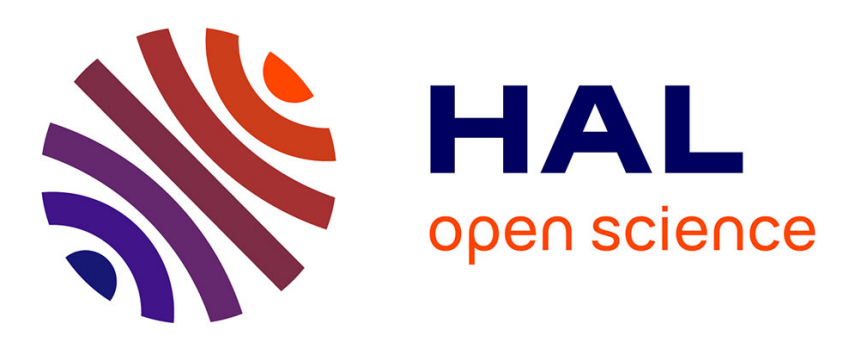

\title{
Alkyl-Modified Gold Surfaces: Characterization of the Au-C Bond
}

\author{
Avni Berisha, Catherine Combellas, Fredeŕic Kanoufi, Jérôme Médard, \\ Philippe Decorse, Claire Mangeney, Issam Kherbouche, Mahamadou Seydou, \\ Francois Maurel, Jean Pinson
}

\section{To cite this version:}

Avni Berisha, Catherine Combellas, Fredeŕic Kanoufi, Jérôme Médard, Philippe Decorse, et al.. Alkyl-Modified Gold Surfaces: Characterization of the $\mathrm{Au}-\mathrm{C}$ Bond. Langmuir, 2018, 10.1021/acs.langmuir.8b01584 . hal-02359178

\section{HAL Id: hal-02359178 https://hal.science/hal-02359178}

Submitted on 12 Nov 2019

HAL is a multi-disciplinary open access archive for the deposit and dissemination of scientific research documents, whether they are published or not. The documents may come from teaching and research institutions in France or abroad, or from public or private research centers.
L'archive ouverte pluridisciplinaire HAL, est destinée au dépôt et à la diffusion de documents scientifiques de niveau recherche, publiés ou non, émanant des établissements d'enseignement et de recherche français ou étrangers, des laboratoires publics ou privés. 


\title{
Alkyl-Modified Gold Surfaces: Characterization of the Au-C Bond
}

\author{
Avni Berisha, ${ }^{*},{ }^{\dagger} \S$ Catherine Combellas, ${ }^{\dagger}$ Frédéric Kanouf, ${ }^{\dagger}{ }^{\dagger}$ Jérôme Médard, ${ }^{\dagger}$ Philippe Decorse, ${ }^{\dagger}$ \\ Claire Mangeney, ${ }^{\ddagger}$ Issam Kherbouche, ${ }^{\ddagger}$ Mahamadou Seydou, ${ }^{\dagger}$ François Maurel, ${ }^{\dagger}{ }^{\dagger}$ and Jean Pinson ${ }^{*}, \dagger^{\dagger}$ \\ †Sorbonne Paris Cité, Université Paris Diderot, ITODYS, UMR 7086 CNRS, 15 rue J-A de Baif, 75013 Paris, France \\ ${ }^{\ddagger}$ Sorbonne Paris Cité, Université Paris Descartes, Laboratoire de Chimie et Biochimie Pharmacologiques et Toxicologiques, UMR \\ 8601 CNRS, 45 rue des Saints Pères, 75006 Paris, France \\ ${ }^{\S}$ Chemistry Department of Natural Sciences Faculty, University of Prishtina, rr. "Nëna Tereze” nr. 5, 10000 Prishtina, Kosovo
}

Supporting Information

ABSTRACT: The surface of gold can be modified with alkyl groups through a radical crossover reaction involving alkyliodides or bromides in the presence of a sterically hindered diazonium salt. In this paper, we characterize the $\mathrm{Au}-\mathrm{C}(\mathrm{alkyl})$ bond by surface-enhanced Raman spectroscopy (SERS); the corresponding peak appears at $387 \mathrm{~cm}^{-1}$ close to the value obtained by theoretical modeling. The $\mathrm{Au}-\mathrm{C}$ (alkyl) bond energy is also calculated, it reaches $-36.9 \mathrm{kcal} \mathrm{mol}^{-1}$ similar to that of an $\mathrm{Au}-\mathrm{S}-\mathrm{alkyl}$ bond but also of an $\mathrm{Au}-\mathrm{C}(\mathrm{aryl})$ bond. In agreement with the similar energies of $\mathrm{Au}-$

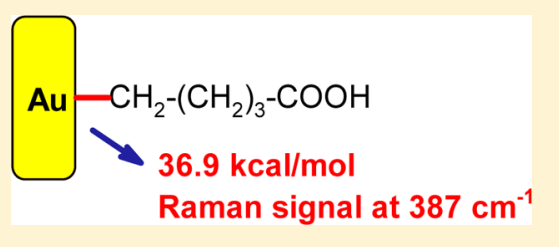
$\mathrm{C}(\mathrm{alkyl})$ and $\mathrm{Au}-\mathrm{S}-(\mathrm{alkyl})$, we demonstrate experimentally that these groups can be exchanged on the surface of gold.

\section{INTRODUCTION}

Surface modification by organic films is commonly encountered in our daily life from a painted house gate to the sophisticated processes that prevent cars from rusting and provide the aesthetic finish. Among the many routes that have been developed, some provide a chemical bond between the surface and the organic film. For example, self-assembled monolayers (SAMs) of silanes, ${ }^{1-3}$ phosphonates, ${ }^{4,5}$ and carboxylic acids ${ }^{6}$ are formed on surface oxides, while alkenes and alkynes are bonded to hydrogenated silicon ${ }^{7}$ or carbon. ${ }^{8}$ Long alkyl chain thiols SAMs are attached to gold and some other metals ( $\mathrm{Ag}$ and $\mathrm{Cu}) .{ }^{9}$ Electrografting strategies have also been investigated such as the electrografting of diazonium salts, which provides aryl films covalently bonded to a variety of surfaces (carbon, metals, oxides, polymers). ${ }^{10-13}$ These different methods provide a number of surface-(organic film) bonds; for example, silanes are bonded through (surface oxygen)-silicon: $\mathrm{O}-\mathrm{Si}$ bonds, carboxylates through $\mathrm{O}-\mathrm{C}$ bonds, ${ }^{1}$ thiols through $\mathrm{Au}-\mathrm{S}$ bonds, ${ }^{9}$ and diazonium salts $^{10-12,14}$ through metal-C(aryl) or oxide $\mathrm{O}-\mathrm{C}($ aryl $)$. Alkyl films bonded to various surfaces have been prepared by (i) electrochemical oxidation of carboxylates ${ }^{15}$ on carbon anodes and Grignard reagents ${ }^{16}$ on hydrogenated silicon and (ii) by electrochemical reduction of iodoalkanes ${ }^{17}(\mathrm{RI})$ or perfluoroiodoalkanes $\left(\mathrm{R}_{\mathrm{F}}-\left(\mathrm{CH}_{2}\right)_{2}-\mathrm{I}\right)$ on glassy carbon, $\mathrm{Au}$, $\mathrm{Fe}$, and $\mathrm{Cu}$ cathodes. However, for the latter process, the reduction takes place at quite negative potentials, which results in the reduction of any reducible group in the film. More recently, it was found that the reaction can be accomplished indirectly at much lower driving force ${ }^{18}$ following Scheme 1.

The 2,6-dimethylbenzenediazonium (DMBD) salt is reduced electrochemically at quite low potential $\left[E_{\mathrm{p}}=-0.20 \mathrm{~V} /\right.$ saturated calomel electrode (SCE) to its radical [R1]]; however, because of steric hindrance this radical cannot react
Scheme 1. Indirect Grafting of Alkyliodides

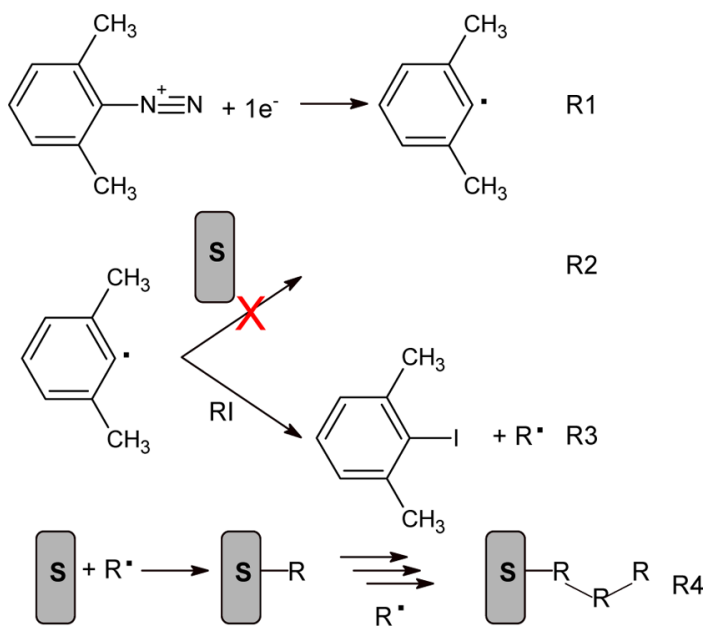

with surfaces [R2], instead it abstracts a iodine atom from RI present in the solution to give the alkyl radical $\mathrm{R}^{\bullet}[\mathrm{R} 3]$ that reacts with the surface (R4). In the case of $\mathrm{RI}=\mathrm{C}_{6} \mathrm{~F}_{13}-$ $\left(\mathrm{CH}_{2}\right)_{2}-\mathrm{I}$, the direct reduction takes place at $E_{\mathrm{p}}=-1.9 \mathrm{~V} /$ SCE and the electrografting reaction can be achieved at the reduction potential of 2,6-DMBD with a potential gain of $\Delta V$ $\approx 1.7 \mathrm{~V}$. This indirect grafting of alkyl groups has been extended to alkyl bromides, ${ }^{19}$ to the formation of mixed layers, ${ }^{20}$ and to the surface modification of polymers. ${ }^{21}$

The bond between the surface and an aryl group grafted by reduction of diazonium salts has been well characterized by

Received: May 14, 2018

Revised: July 18, 2018

Published: September 1, 2018 
theoretical calculations, ${ }^{12,22-24}$ Raman (graphene-aryl ${ }^{25}$ ), surface-enhanced Raman scattering (SERS) (Au-aryl $\left.{ }^{14}\right)$, X-ray photoelectron spectroscopy (XPS) ( $\mathrm{Fe}-\operatorname{aryl},{ }^{26} \mathrm{O}$-aryl, ${ }^{27} \mathrm{Au}-$ $\mathrm{N}=\mathrm{N}-\operatorname{aryl}^{28}$ ), time-of-flight secondary ion mass spectrometry (C and $\mathrm{O}-$ aryl), ${ }^{29}$ and Mossbauer spectroscopy (O-aryl). ${ }^{30}$ The energies of the surface-aryl bond vary from 24 to 30 and $70 \mathrm{kcal} \mathrm{mol}^{-1}$ for, respectively, $\mathrm{Au}^{23}$ a graphene plane, ${ }^{31}$ and $\mathrm{Si}^{23}$ However, there are no such results for the surface-alkyl bonds that have never been characterized.

Herein, we examine (i) the Raman spectroscopic evidence of an Au-alkyl bond, (ii) the growth of the film by atomic force microscopy (AFM), (iii) the bonding energy of alkyl groups ( $\mathrm{Au}-\mathrm{C}$ bond) on gold by theoretical methods and we compare this energy to that of the previously investigated $\mathrm{Au}-\mathrm{S}-$ alkyl bond, and (iv) based on the results of the simulations, we show that alkyl and thioalkyl groups can be exchanged on the surface of gold [the valeric groups of a $\mathrm{Au}-\left(\mathrm{CH}_{2}\right)_{4}-\mathrm{COOH}$ film, prepared from bromovaleric acid (Scheme 1), are exchanged by the $\mathrm{HS}-\left(\mathrm{CH}_{2}\right)_{5}-\mathrm{COOH}$ and $\mathrm{HS}-\left(\mathrm{CH}_{2}\right)_{17} \mathrm{CH}_{3}$ thiols].

\section{MATERIALS AND METHODS}

2.1. Chemicals. 5 -Bromovaleric acid (97\%), valeric acid (99\%), 2,6-dimethylaniline (99\%), tetrabutylammonium tetrafluoroborate (99\%), 1-octadecanethiol (99\%), 6-mercaptohexanoic acid (90\%), acetonitrile $(\mathrm{ACN})$, and diethyl ether were purchased from SigmaAldrich. They were used without further purification. Milli-Q water $(>18 \mathrm{M} \Omega \mathrm{cm})$ and absolute ethanol were used for rinsing the samples. 2,6-DMBD was prepared by the standard procedure in aqueous solution. ${ }^{32}$ The product was purified by dissolution in ACN and precipitation in ether. IR-ATR: $-\mathrm{N}_{2}^{+}: 2269 \mathrm{~cm}^{-1}$, aromatic vibrations: $1585,1478 \mathrm{~cm}^{-1}, \mathrm{BF}_{4}^{-}: 1036 \mathrm{~cm}^{-1}, \mathrm{C}-\mathrm{H}$ out of plane: $806 \mathrm{~cm}^{-1} .{ }^{1} \mathrm{H}$ NMR (DMSO- $d_{6}$, Bruker $\left.400 \mathrm{MHz}\right) \delta \mathrm{ppm}: 8.02(\mathrm{t}$, $1 \mathrm{H}), 7.65(\mathrm{~d}, 2 \mathrm{H}), 2.95(\mathrm{~s}, 6 \mathrm{H})$.

2.2. Substrates. Gold-coated silicon wafers $(100 \mathrm{~nm})$ were obtained from Sigma-Aldrich and cut into $1 \times 1 \mathrm{~cm}^{2}$ plates, immersed in concentrated sulfuric acid and thoroughly rinsed in ultrapure water and then absolute alcohol. Nanostructured indium tin oxide (ITO)/ $\mathrm{Au}$ surfaces were obtained by depositing gold onto ITO-coated glass slides, using the vacuum sputtering method ( $\mathrm{dc}$ Ar plasma, gas purity-99.995\%, gas pressure $4 \mathrm{~Pa}$, discharge power $7.5 \mathrm{~W}$, sputtering time $120 \mathrm{~s}$, resulting thickness 5-6 nm). Targets for metal deposition were purchased from Safina.

2.3. Functionalization of $\mathrm{Au}$ Plates and ITO/Au(Nanostructured) Electrodes by Alkyl Groups. Electrografting was performed by chronoamperometry $(E=-0.5 \mathrm{~V} / \mathrm{SCE}$ for $300 \mathrm{~s})$ in $\mathrm{ACN}+0.1 \mathrm{M} \mathrm{NBu}_{4} \mathrm{PF}_{6}$ solutions containing $20 \mathrm{mM}$ of 2,6-DMBD and $100 \mathrm{mM}$ of bromovaleric acid. The "thin" and "thick" films used to discuss the growth of the film were prepared as follows in ACN + $0.1 \mathrm{M} \mathrm{NBu}_{4} \mathrm{PF}_{6}$ : "thin" film: $30 \mathrm{mM}$ bromovaleric acid, $7 \mathrm{mM} \mathrm{2,6-}$ DMBD, and six voltammetric cycles between +0.3 and $-0.5 \mathrm{~V} / \mathrm{SCE}$ at $0.1 \mathrm{~V} \mathrm{~s}^{-1}$; "thick" film: $100 \mathrm{mM}$ bromovaleric acid, $20 \mathrm{mM} \mathrm{2,6-}$ DMBD, and 50 voltammetric cycles between +0.3 and $-0.5 \mathrm{~V} / \mathrm{SCE}$ at $0.1 \mathrm{~V} \mathrm{~s}^{-1}$.

2.4. Electrochemical Measurements. Electrochemical experiments were performed with an Ametek, Princeton Applied Research, VersaSTAT 4 potentiostat/galvanostat and a VersaStudio electrochemistry software 2.44.4 version software. All experiments were carried out in ACN solutions deoxygenated with argon. All potentials are referred to the SCE electrode, the counter electrode was a large platinum mesh. After grafting, the modified gold surfaces were rinsed in acetone under sonication for $8 \mathrm{~min}$ and then in absolute ethanol.

2.5. IR Spectra. The infrared reflection-absorption spectroscopy (IRRAS) and attenuated total reflection (ATR) spectra of modified plates were recorded using a purged (low $\mathrm{CO}_{2}$, dry air) Jasco FT/IR6100 Fourier transform infrared spectrometer equipped with a mercury-cadmium-telluride detector. For each spectrum, 1000 scans were accumulated with a spectral resolution of $4 \mathrm{~cm}^{-1}$. The background recorded before each spectrum was that of a clean substrate. ATR spectra were recorded with a germanium ATR accessory (Jasco ATR PR0470-H).

2.6. Raman Spectra. The SERS spectra were recorded with a Jobin Yvon LabRam HR 800 microspectrometer in backscattering configuration, using an excitation line of $785 \mathrm{~nm}$ with a power of 0.6 $\mathrm{mW}$. All spectra were recorded in air within the $150-2700 \mathrm{~cm}^{-1}$ spectral range. The scattered light was collected with a long working distance objective of 100 -fold magnification (0.9 NA). The spectral resolution was less than $3 \mathrm{~cm}^{-1}$. The accumulation time for the SERS measurements was set to $10 \mathrm{~s}$ with five repetitions.

2.7. XPS Spectra. XPS measurements were performed using a KAlpha system (Thermo Fisher Scientific, East-Grinstead, UK) fitted with a microfocused and monochromatic $\mathrm{Al} \mathrm{K} \alpha \mathrm{X}$-ray source (1486.6 $\mathrm{eV}$, spot size: $400 \mu \mathrm{m}$ ). The pass energy was set to 150 and $40 \mathrm{eV}$ for the survey and the high resolution spectra, respectively. The spectra were calibrated against the $\mathrm{C}-\mathrm{C} / \mathrm{C}-\mathrm{H} \mathrm{C} 1$ s component set at 285 $\mathrm{eV}$. The chemical composition was determined with version 5.977 Avantage software, by using the manufacturer sensitivity factors. The spectra were calibrated against C 1 s set at $285 \mathrm{eV}$.

2.8. Ellipsometry. Thicknesses of the films on gold plates were measured with a mono wavelength ellipsometer Sentech SE400 with an SE400 advanced 2.20 version software. The following values were taken for gold: $n s=0.207$ and $k s=3.41$; they were measured on clean surfaces before using the plates for grafting. The film thicknesses were determined from the same plates after modification, taking $\mathrm{ns}=1.46$ and $\mathrm{ks}=0$ for the layer.

2.9. Contact Angle Measurements. The water interaction properties were characterized with a drop shape analysis system Krüss DSA30S and a Drop Shape Analysis 1.92.1.1 version software.

2.10. AFM Images. AFM images were recorded with a NT-MDT Solver pro equipment. AFM topography was performed in the intermittent contact mode with standard silicon cantilevers. Image analysis was achieved with the free software WSxM.

2.11. Computational Methods. Calculations on $\mathrm{Au}$ clusters were performed using the Gaussian 09 suite of programs. ${ }^{33}$ The gold $\mathrm{Au} 20$ cluster was used to model the grafting of both Au20- $\left(\mathrm{CH}_{2}\right)_{4}-$ $\mathrm{COOH}$ and $\mathrm{Au} 20-\mathrm{S}-\left(\mathrm{CH}_{2}\right)_{5}-\mathrm{COOH}$. This cluster proved to be a reliable model for the calculation of bond energies. ${ }^{34}$ The geometry optimizations (run without symmetry constrains) were performed using the density functional method (DFT) at B3LYP level. The 6$3 \lg (\mathrm{d})$ basis sets were used to describe $\mathrm{S}, \mathrm{C}, \mathrm{H}, \mathrm{O}$ atoms, whereas the LanL2DZ basis set was used for gold atoms. All energy minima were characterized by performing a vibrational analysis to ensure the lack of imaginary frequencies. ${ }^{12}$ For the most stable structures, in addition to infrared intensities, Raman intensities were computed. The visualization of three-dimensional structures and the analysis of the results were done by using Chemcraft or the free version of Mercury software.

To optimize the system and calculate the binding energy of the bond between the molecule and the surface, we used periodic DFT calculations. These bond energies are defined as the difference between the energy of the complex $(\mathrm{Au}+\mathrm{M})$ and the energies of the isolated molecule $(\mathrm{M})$ and the bare surface $(\mathrm{Au})$. The gold surface model used was $\mathrm{Au}(111)$ plane with four slab layers (12 Au atoms in each layer) with the supercell $(2 \sqrt{3} \times \sqrt{3}) R 30^{\circ}$ (containing one valeric acid or thiohexanoic group per 12 gold surface atoms). The generalized gradient approximation was used with the PerdewBurke-Ernzerhof (PBE) functional ${ }^{35}$ at PBE level of calculation ${ }^{36}$ under periodic boundary conditions as implemented in VASP 5.4.1 software. ${ }^{37}$ The electron-ion interactions were described by the projector augmented wave ${ }^{38}$ method, representing the valence electrons, as provided in the code libraries. The convergence of the plane-wave expansion was obtained using a cut off of $500 \mathrm{eV}$. The integration over the Brillouin zone was performed on $3 \times 6 \times 1 k$ point mesh. The convergence tolerance in the electronic selfconsistency loop was $10^{-4} \mathrm{eV} /$ cell, while convergence in the relaxation of the ionic positions was defined by all force components falling below $1 \mathrm{meV} / \AA$. The slab models were constructed using Model view software. 


\section{RESULTS AND DISCUSSION}

3.1. Raman Evidence of the Au-Alkyl Bond. To evidence the existence of the bond between the Au surface and the valeric acid group, the Raman SERS spectrum of $\mathrm{Au}-$ $\left(\mathrm{CH}_{2}\right)_{4}-\mathrm{COOH}$ was recorded on a SERS active surface, and the $\mathrm{Au}-\mathrm{C}$ bond was assigned by comparison with a calculated spectrum. The experimental spectrum shows a peak at 387 $\mathrm{cm}^{-1}$ assigned to the $\mathrm{Au}-\mathrm{C}$ bond (Figure $1 \mathrm{~b}$ ); it is neither

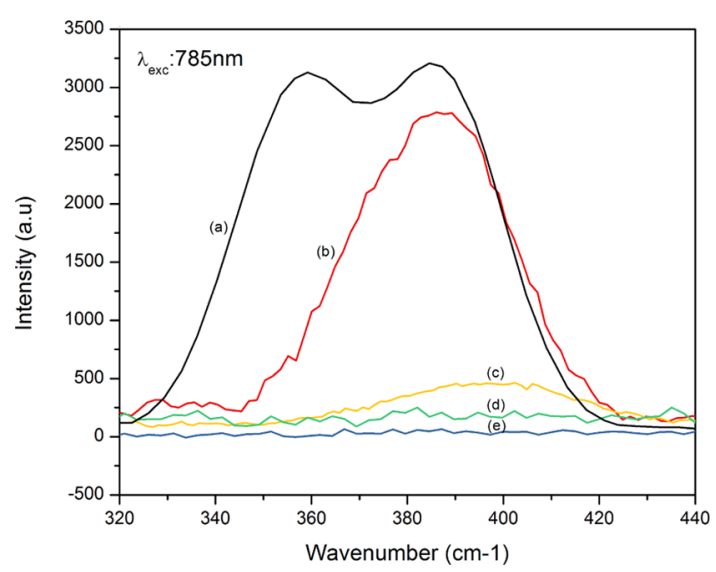

Figure 1. (a) Calculated Raman spectrum of Au20-( $\left.\mathrm{CH}_{2}\right)_{4}-\mathrm{COOH}$ and $(\mathrm{b}-\mathrm{e})$ experimental SERS spectra of (b) $\mathrm{Au}-\left(\mathrm{CH}_{2}\right)_{4}-\mathrm{COOH}$, (c) $\mathrm{Br}-\left(\mathrm{CH}_{2}\right)_{4}-\mathrm{COOH}$, (d) $\mathrm{CH}_{3}-\left(\mathrm{CH}_{2}\right)_{3}-\mathrm{COOH}$, and (e) bare $\mathrm{Au}$ surface. (c,d) Deposited on the surface. Experimental spectra recorded under identical conditions.

observed in a blank spectrum of the surface nor in bromovaleric acid or valeric acid (Figure 1e,c,d, respectively). The position of this Raman peak is close to that previously observed at $412 \mathrm{~cm}^{-1}$ on gold nanoparticles modified with 4nitrobenzenediazonium and assigned to the signature of the $\mathrm{Au}-\mathrm{C}($ aryl $)$ bond on the basis of DFT calculations. ${ }^{14}$

To further ascertain the presence of an $\mathrm{Au}-\mathrm{C}$ (alkyl) bond, the Raman spectrum of $\mathrm{Au} 20-\left(\mathrm{CH}_{2}\right)_{4}-\mathrm{COOH}$ was computed and analyzed (Figure 1a) using potential energy distribution (PED). ${ }^{39}$ Two Raman bands are calculated at 387 and 357 $\mathrm{cm}^{-1}$ (half width at half-maximum: $30 \mathrm{~cm}^{-1}$ ): the first one corresponds to the $\mathrm{Au}-\mathrm{C}$ stretching and the second one to a coupled vibration involving the $\mathrm{Au}-\mathrm{C}$ stretch and the alkyl chain. Both vibrations are absent in the bare Au20 gold cluster, (Figure SI1 in Supporting Information); the $\mathrm{Au}-\mathrm{Au}$ stretching vibrations are located at 155 and $119 \mathrm{~cm}^{-1}$. The $357 \mathrm{~cm}^{-1}$ Raman band does not appear in the experimental spectra, either it is not present when the alkyl chains are closely packed on the surface or the two 387 and $357 \mathrm{~cm}^{-1}$ bands are not resolved (see overall Raman spectrum in Supporting Information, Figure SI1B). In the calculated spectrum of Au20-S- $\left(\mathrm{CH}_{2}\right)_{5}-\mathrm{COOH}$, the stretching vibrations of $\mathrm{Au}-\mathrm{S}$ are observed at 269 and $241 \mathrm{~cm}^{-1}$, in full agreement with those previously calculated for an Au25-thiol cluster. ${ }^{40}$ The comparison of the experimental and simulated spectra permits to demonstrate the existence of an $\mathrm{Au}-\mathrm{C}$ bond in the modified gold surface (Table 1).

3.2. Growth of the Film. The film grows by attack of the first grafted group by the $\mathrm{R}^{\bullet}$ radicals (Scheme 1, reaction [R4]) as observed for other radical reactions. ${ }^{10,11}$ The growth of the film was followed by recording the AFM images of a bare gold sample grafted with a "thin" film (th $<1 \mathrm{~nm})$ and a "thick" one $(\mathrm{th}=5.7 \pm 1.5 \mathrm{~nm})$ (see Experimental Section). The length of
Table 1. Calculated and Experimental Raman Spectra ${ }^{a}$

$\begin{array}{ccc} & \begin{array}{c}\text { wavenumber }\left(\mathrm{cm}^{-1}\right) \\ \text { calculated }^{a}\end{array} & \text { experimental } \\ & \text { Au20 } & \\ & 155,119 & \\ \nu_{\text {AuAu }} & \mathbf{A u 2 0}-\left(\mathbf{C H}_{2}\right)_{4}-\mathbf{C O O H} & 387 \\ & 387 & \\ \nu_{\text {AuC }} & 165,118 & \\ \nu_{\text {AuAu }} & \mathbf{A u 2 0}-\mathbf{S}\left(\mathbf{C H}_{2}\right)_{5}-\mathbf{C O O H} & \\ & 269,241\end{array}$

${ }^{a}$ Calculated vibrational wavenumbers as assigned from PED analysis.

a $\left(\mathrm{CH}_{2}\right)_{4}-\mathrm{COOH}$ group, obtained from a molecular model, is $\sim 0.9 \mathrm{~nm}$; therefore, these two films are respectively close to a monolayer and a multilayer; the growth of alkyl films that results from unselective reaction of alkyl radicals has already been described. ${ }^{20,21}$ The commercial gold surface on silicon wafers presents olive-shaped structures, the height of which reaches $4 \mathrm{~nm}$. On the "thin" film the structures of gold are less pronounced $(\sim 2 \mathrm{~nm})$, which indicates that the valleys are filled before the summits of the structure. With the "thick" film, clumps of organic matter are observed with a height that reaches $6 \mathrm{~nm}$ (Figure 2).

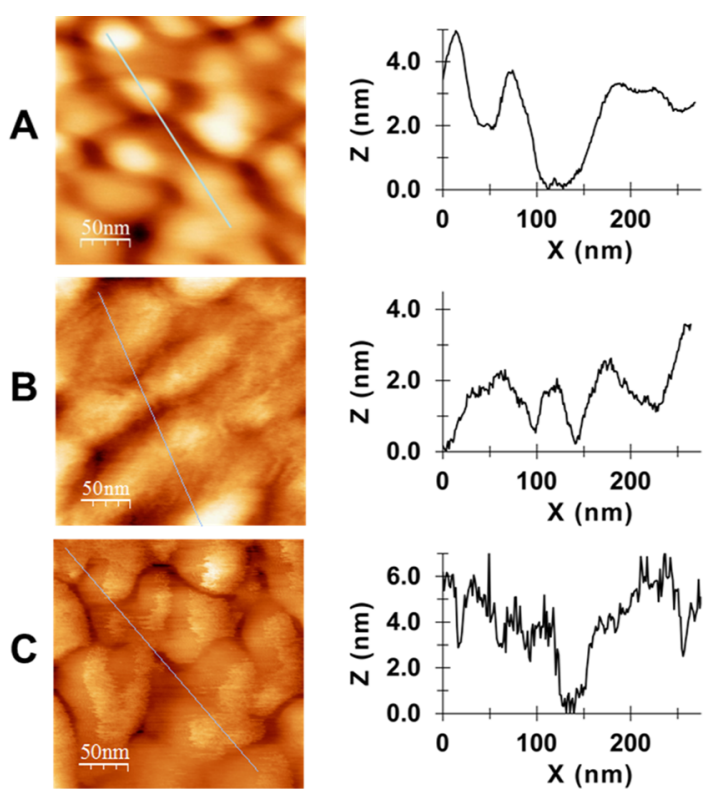

Figure 2. AFM images of (A) bare gold substrate, (B) "thin" (th $<1$ $\mathrm{nm})$, and $(\mathrm{C})$ "thick" (th $=5.7 \mathrm{~nm}) \mathrm{Au}\left(\mathrm{CH}_{2}\right)_{4}-\mathrm{COOH}$ film.

3.3. Evaluation of Bonding Energies on an Au Slab. The bonding energies between the gold surface and the organic group were evaluated by VASP calculations for $\mathrm{Au}(111)-\left(\mathrm{CH}_{2}\right)_{4}-\mathrm{COOH}$ and $\mathrm{Au}(111)-\mathrm{S}-\left(\mathrm{CH}_{2}\right)_{5}-$ $\mathrm{COOH}$ for different binding sites of the slab (Table 2, Figures 3 , and SI2 in Supporting Information for the different binding sites). For $\mathrm{Au}(111)-\left(\mathrm{CH}_{2}\right)_{4}-\mathrm{COOH}$, the $\mathrm{Au}-\mathrm{C}$ bond is the strongest for the TOP site: $-36.9 \mathrm{kcal} / \mathrm{mol}$, while for the $\mathrm{Au}(111)-\mathrm{S}-\left(\mathrm{CH}_{2}\right)_{5}-\mathrm{COOH}$ this occurs at the FCC site: $-45.5 \mathrm{kcal} / \mathrm{mol}$ (FCC sites are, in general, the preferred binding sites for thiols ${ }^{42}$ ). In the literature, the binding energy of alkylthiols varies from $-25 \mathrm{kcal} / \mathrm{mol}$ for conjugated molecules to $-44 \mathrm{kcal} / \mathrm{mol}$ depending on the length and the chemical structure. ${ }^{41,42}$ The above values can also be compared 
Table 2. Computed Bonding Energies to Periodic Surfaces ${ }^{a}$

\begin{tabular}{|c|c|c|c|c|c|}
\hline & TOP & $\mathrm{BRD}$ & FCC & HCP & planar \\
\hline $\left.\mathrm{Au}(111)-\left(\mathrm{CH}_{2}\right)_{4}-\mathrm{COOH}\right)$ & -36.9 & -34.2 & -32.1 & -34.1 & -4.6 \\
\hline $\mathrm{Au}(111)-\mathrm{S}-\left(\mathrm{CH}_{2}\right)_{5}-\mathrm{COOH}$ & -31.6 & -36.3 & -45.5 & -38.9 & -34.0 \\
\hline
\end{tabular}

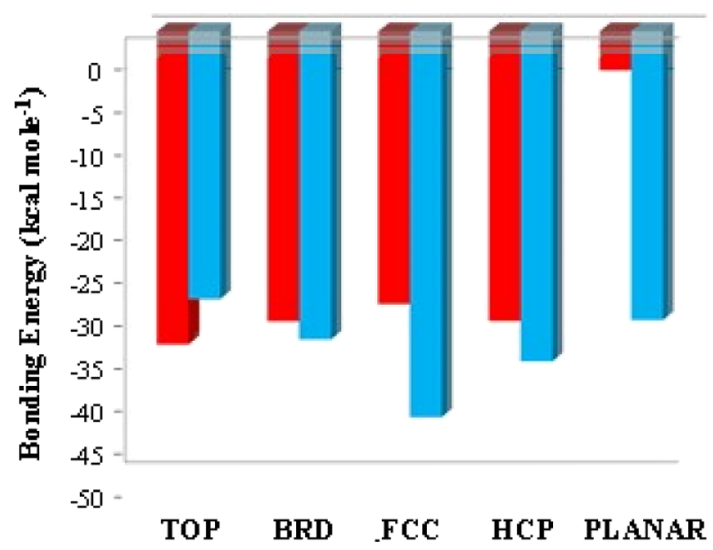

Figure 3. Computed bonding energies for (red) $\mathrm{Au}(111)-\left(\mathrm{CH}_{2}\right)_{4}-$ $\mathrm{COOH}$ and (blue) $\mathrm{Au}(111)-\mathrm{S}-\left(\mathrm{CH}_{2}\right)_{5}-\mathrm{COOH}$.

with that calculated (with two different methods) for $\mathrm{Au}-$ $\mathrm{C}$ (aryl) bonds obtained by grafting diazonium salts on gold: $-34.4 \mathrm{kcal} / \mathrm{mol}\left(\mathrm{Au} 19-\mathrm{C}_{6} \mathrm{H}_{5}\right)^{12}$ and $-24.0 \mathrm{kcal} / \mathrm{mol}$ $[\mathrm{Au}(111)$, TOP site $]-\mathrm{C}_{6} \mathrm{H}_{5}{ }^{23}$ These calculations indicate that the energy of $\mathrm{Au}(111)-\mathrm{C}(\mathrm{alkyl})$ bond is equivalent to that of an $\mathrm{Au}-\mathrm{C}(\operatorname{aryl})$ bond; the $\mathrm{Au}(111)-\mathrm{S}-$ alkyl bond is more stable than the $\mathrm{Au}(111)-\mathrm{C}($ alkyl $)$ one by $-8.6 \mathrm{kcal} / \mathrm{mol}$.

The lengths for $\mathrm{Au}-\mathrm{C}(\mathrm{alkyl})$ (TOP site) and $\mathrm{Au}-\mathrm{S}$ (FCC site) bonds are, respectively, 2.30 and $2.03 \AA$ (deduced from Figure 4). The geometries of the bonded molecules (periodic
A.

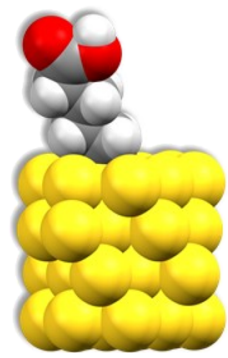

B.

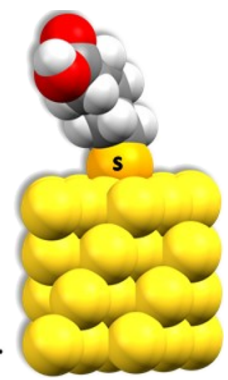

Figure 4. Optimized structures for (A) $\mathrm{Au}(111)-\left(\mathrm{CH}_{2}\right)_{4}-\mathrm{COOH}$ (TOP) and (B) $\mathrm{Au}(111)-\mathrm{S}-\left(\mathrm{CH}_{2}\right)_{5}-\mathrm{COOH}(\mathrm{BRD})$ on periodic surfaces.

calculations) are almost identical for $\mathrm{Au}(111)-\left(\mathrm{CH}_{2}\right)_{4}-$ $\mathrm{COOH}$ (TOP) and $\mathrm{Au}(111)-\mathrm{S}-\left(\mathrm{CH}_{2}\right)_{5}-\mathrm{COOH}$ (BRD), and there is no apparent pulling of gold atoms from the surface. Considering the above computed bond energies that indicate a significant difference of $\sim-8.6 \mathrm{kcal} / \mathrm{mol}$ between the two grafted molecules, one should, in principle, be able to replace reversibly the bonded moiety. This idea of replacement of the grafted moiety is further elaborated experimentally.

3.4. Comparison with the Au20 Gold Cluster. The results of the above periodic calculations can be compared with that of nonperiodic DFT calculations on an Au20 cluster. As already observed in the grafting of aryl groups, ${ }^{12}$ binding an alkyl group (valeric group) to the surface of Au20 changes its geometry (Figure 5). The bond distances between neighboring gold atoms change after the grafting: in the bare cluster

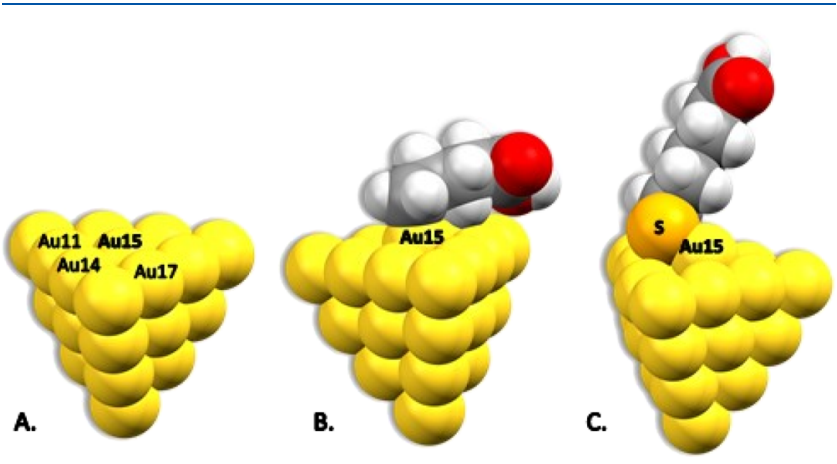

Figure 5. Optimized structures for (A) Au20 cluster, (B) Au20$\left(\mathrm{CH}_{2}\right)_{4}-\mathrm{COOH}$, and $(\mathrm{C}) \mathrm{Au} 20-\mathrm{S}-\left(\mathrm{CH}_{2}\right)_{5}-\mathrm{COOH}$ grafted clusters.

$d(\mathrm{Au15}-\mathrm{Au} 17)=d(\mathrm{Au15}-\mathrm{Au} 14)=2.90 \AA$, while after grafting to Au15 the gold atom distance changes: d(Au15Au17 $) / d($ Au15-Au14 $)=3.03$, indicating an effect similar to that observed in the case of thiols and aryl radicals. ${ }^{9,12}$ The dihedral angles are also modified: (Au17-Au15-Au11-Au14) is $3.6^{\circ}$ for $\mathrm{Au} 20$ but $20.0^{\circ}$ in $\mathrm{Au} 20-\left(\mathrm{CH}_{2}\right)_{3}-\mathrm{COOH}$. After grafting, the gold atom is pulled out from the mean surface plane of the Au20 cluster by about $0.86 \AA$ (Figure 5). This demonstrates that a strong interaction takes place. Such an interaction is known for thiols through DFT calculations and $\mathrm{STM}^{43}$ and also from the X-ray structure of a $p$ mercaptobenzoic acid ( $p$-MBA)-protected gold nanoparticle (102 gold atoms and $44 p$-MBA groups). ${ }^{44}$

Similar effects have been observed for Au20-S- $\left(\mathrm{CH}_{2}\right)_{5}-$ $\mathrm{COOH}$, where $d(\mathrm{Au} 15-\mathrm{Au} 17)=2.90 \AA$, whereas $d(\mathrm{Au} 15-$ Au14) = 3.51 A; the dihedral angle for (Au17-Au15-Au11Au14) is $19.5^{\circ}$, and the gold atom is pulled by $1.11 \AA$ from the surface.

3.5. Comparison of $\mathrm{Au}-\mathrm{C}$ and $\mathrm{Au}-\mathrm{S}$ Stabilities. Because the above calculations indicate that Au-alkyl and $\mathrm{Au}-\mathrm{S}-$ alkyl have similar energies, the possible exchange of the valeric group of $\mathrm{Au}-\left(\mathrm{CH}_{2}\right)_{4}-\mathrm{COOH}$ by an octadecylthiol group to give $\mathrm{Au}-\mathrm{S}-\left(\mathrm{CH}_{2}\right)_{17}-\mathrm{CH}_{3}$ was tested (note that reactions [R5] and [R6] below are not equilibrated; they are not chemical equations, they are only used as a basis of discussion). McDermott previously showed that it is possible to partially replace the grafted aryl groups derived from diazonium $\left(\mathrm{Au}-\mathrm{C}_{6} \mathrm{H}_{4}-\mathrm{NO}_{2}\right)$ by arylthiol groups $(\mathrm{Au}-\mathrm{S}-$ $\left.\mathrm{C}_{6} \mathrm{H}_{4}-\mathrm{NO}_{2}\right)$.

$$
\begin{aligned}
\mathrm{Au}-\left(\mathrm{CH}_{2}\right)_{4}-\mathrm{COOH}+\mathrm{CH}_{3}-\left(\mathrm{CH}_{2}\right)_{17}-\mathrm{SH} \\
\underset{\mathrm{R} 5 \mathrm{~b} 5 \mathrm{Au}}{\rightleftarrows} \mathrm{S}-\left(\mathrm{CH}_{2}\right)_{17}-\mathrm{CH}_{3}+\mathrm{CH}_{3}-\left(\mathrm{CH}_{2}\right)_{3}-\mathrm{COOH}
\end{aligned}
$$

To test this hypothesis, a gold plate was first modified as indicated in the experimental section (film thickness: th $=2.5$ $\pm 1.0 \mathrm{~nm}$, water contact angle $\left.\theta=61 \pm 4^{\circ}\right)$, immersed for $24 \mathrm{~h}$ 
in a deoxygenated solution of octadecanethiol $\left(\mathrm{CH}_{3}-\right.$ $\left.\left(\mathrm{CH}_{2}\right)_{17}-\mathrm{SH}\right)$ (long-chain thiols are adsorbed preferentially over shorter chains ${ }^{46}$ ) and finally rinsed in ethanol under ultrasonication. The IRRAS spectrum was recorded before and after the exchange (Figure 6).
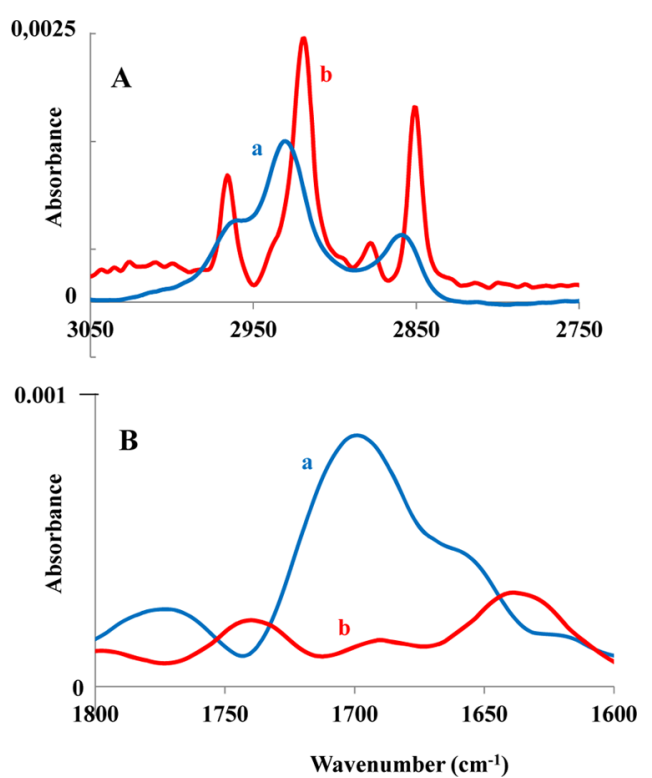

Figure 6. IRRAS spectra of (a) $\mathrm{Au}-\left(\mathrm{CH}_{2}\right)_{4}-\mathrm{COOH}$ and (b) after [R5f] exchange of the surface film by $\mathrm{C}_{18} \mathrm{H}_{37} \mathrm{SH}$ to give $\mathrm{Au}-\mathrm{S}-$ $\left(\mathrm{CH}_{2}\right)_{17}-\mathrm{CH}_{3}$. (A) $\mathrm{CH}$ stretching region, (B) carbonyl region.

The spectrum of $\mathrm{Au}-\left(\mathrm{CH}_{2}\right)_{4}-\mathrm{COOH}$ is characterized by the bands of the four $\mathrm{CH}_{2}$ groups: 2958, 2930, $2858 \mathrm{~cm}^{-1}$ (2963, 2937, $2877 \mathrm{~cm}^{-1}$ for valeric acid, ${ }^{47} \mathrm{CH}_{3}-\left(\mathrm{CH}_{2}\right)_{3}-$ $\mathrm{COOH})$ and the broad $\mathrm{C}=\mathrm{O}$ band of the carboxylic group at $1695 \mathrm{~cm}^{-1}\left(1712 \mathrm{~cm}^{-1}\right.$ for valeric acid) (note also the broad shoulder at $>1650 \mathrm{~cm}^{-1}$ that could correspond to some esterification of the carboxylic group during ultrasonic rinsing in ethanol). After the exchange reaction [R5f], the $\mathrm{CH}$ stretching vibrations increase and the $\mathrm{C}=\mathrm{O}$ band becomes very small. In the $\mathrm{CH}$ stretching region, the spectrum is similar to that of $\mathrm{Au}-\mathrm{S}-\left(\mathrm{CH}_{2}\right)_{17}-\mathrm{CH}_{3}$ prepared by reacting a gold surface with $\mathrm{C}_{18} \mathrm{H}_{37} \mathrm{SH}$ (Figure SI3 in Supporting Information); it exhibits the vibrations of the alkyl group at 2964, 2918, 2876, and $2850 \mathrm{~cm}^{-1}$ and a very small $\mathrm{C}=\mathrm{O}$ signal corresponding to unexchanged valeric groups. Note that after [R5f] exchange the $\mathrm{CH}$ stretching bands are much narrower ${ }^{48}$ and located at positions characteristic of a crystalline structure (the symmetric and asymmetric $\mathrm{CH}_{2}$ vibrations of $\mathrm{C}_{18} \mathrm{H}_{37} \mathrm{SH}$ are located at 2855 and $2924 \mathrm{~cm}^{-1}$ for the liquid and 2851 and $2918 \mathrm{~cm}^{-1}$ for the crystal). ${ }^{48}$ The crystallinity of the Au-S$\left(\mathrm{CH}_{2}\right)_{17}-\mathrm{CH}_{3}$ film obtained by exchange is not perturbed by the small remaining amounts of valeric acid indicating a segregated structure of the film.

Ultrasonication of a film allows testing qualitatively its stability. All the $\mathrm{Au}-\left(\mathrm{CH}_{2}\right)_{4}-\mathrm{COOH}$ samples examined herein were rinsed in acetone and ethanol under ultrasonication. The same test was applied to $\mathrm{Au}-\mathrm{S}-\left(\mathrm{CH}_{2}\right)_{17}-$ $\mathrm{CH}_{3}$. The spectra before and after sonication are similar (Figure SI3B in Supporting Information), in good agreement with the binding energies calculated above.

The water contact angle of the film after [R5f] exchange, $\theta=$ $100 \pm 1^{\circ}$, indicates that the $\mathrm{Au}-\mathrm{S}-\left(\mathrm{CH}_{2}\right)_{17}-\mathrm{CH}_{3}$ film prepared through [R5f] presents some defects because for the same film prepared directly from $\mathrm{C}_{18} \mathrm{H}_{37} \mathrm{SH}$ in alcohol ${ }^{49} \theta$ $=109 \pm 1^{\circ}$.

In the XPS spectrum of $\mathrm{Au}-\left(\mathrm{CH}_{2}\right)_{4}-\mathrm{COOH}$, the $\mathrm{C}$ 1s peak (Figure $7 \mathrm{~A}$ ) presents three contributions at 284.8, 286.5, and

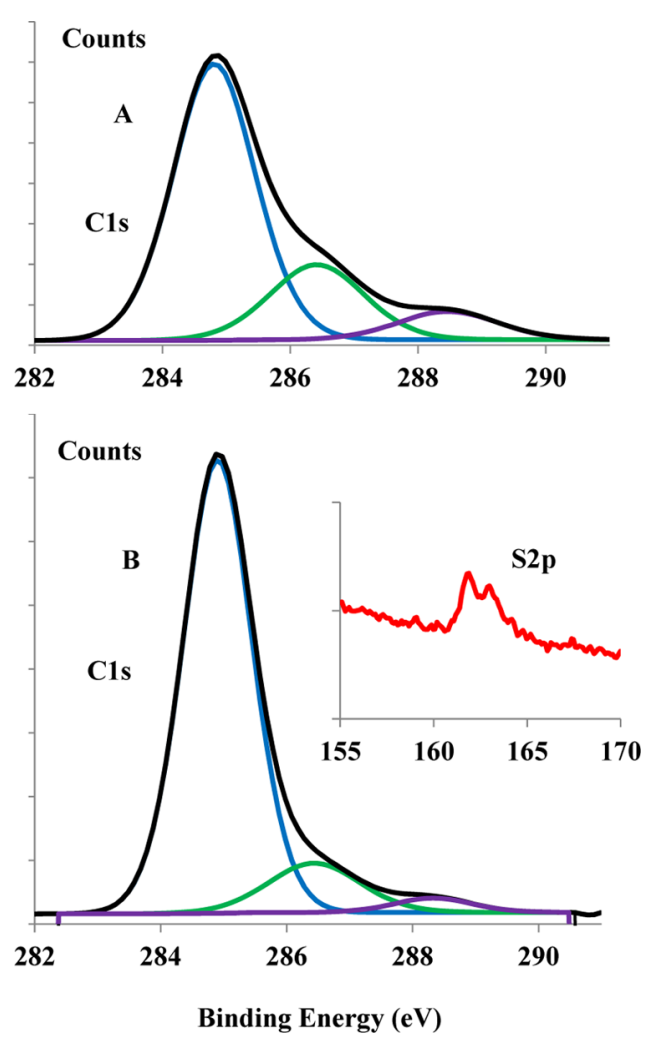

Figure 7. XPS spectrum of (A) $\mathrm{Au}-\left(\mathrm{CH}_{2}\right)_{4}-\mathrm{COOH}$ and (B) $\mathrm{Au}-$ $\mathrm{S}-\left(\mathrm{CH}_{2}\right)_{17}-\mathrm{CH}_{3}$ obtained through the exchange reaction [R5] (C 1s and $S 2 \mathrm{p}$ contributions).

$288.8 \mathrm{eV}$ assigned, respectively, to $\mathrm{C}-\mathrm{C} / \mathrm{C}-\mathrm{H}, \underline{\mathrm{C}} \mathrm{H}_{2}-\mathrm{C}=\mathrm{O}$, and $\mathrm{O}-\underline{\mathrm{C}}=\mathrm{O}$; the last two confirm the presence of the carboxylic group on the surface. The survey spectrum of $\mathrm{Au}-$ $\mathrm{S}-\left(\mathrm{CH}_{2}\right)_{17}-\mathrm{CH}_{3}$ obtained through [R5f] (Figure 7B) shows the presence of $\mathrm{Au} 4 \mathrm{f}(24.1 \%), \mathrm{C} 1 \mathrm{~s}(67.3 \%), \mathrm{N} 1 \mathrm{~s}(1.2 \%), \mathrm{O}$ 1s $(5.5 \%)$, and S $2 \mathrm{p}(1.9 \% ; \mathrm{S} / \mathrm{Au}=0.08)$; it is similar to that of $\mathrm{Au}-\mathrm{S}-\left(\mathrm{CH}_{2}\right)_{17}-\mathrm{CH}$ (Figure SI4 in Supporting Information) obtained directly by dipping a gold plate in the thiol: $\mathrm{Au} 4 \mathrm{f}$ (34.1\%), C 1s (60.5\%), N 1s (0.6\%), O 1s (1.9\%), and S 2p $(3.0 \%, \mathrm{~S} / \mathrm{Au}=0.09)$. However, the $\mathrm{S} / \mathrm{Au}$ ratio is $\sim 10 \%$ lower for the exchanged surface and two small contributions are observed at 286.5 and $288.8 \mathrm{eV}$ that correspond to some remaining valeric groups on the surface. The presence of sulfur on the surface and the strong decrease of the carboxylic signal indicate that $\sim 90 \%$ of the valeric groups have been displaced from the surface by the $\mathrm{C}_{18}$ alkyl chain thiol.

The reverse reaction [R5b] was performed on an $\mathrm{Au}-\mathrm{S}-$ $\left(\mathrm{CH}_{2}\right)_{17}-\mathrm{CH}_{3}$ plate that was submitted to indirect electrografting by bromovaleric acid as in Scheme 1 along the procedure described in the Experimental Section. The IRRAS spectra (Figure 8) show that starting from $\mathrm{Au}-\mathrm{S}-\left(\mathrm{CH}_{2}\right)_{17}-$ $\mathrm{CH}_{3}$ that does not present any band in the $1800-1600 \mathrm{~cm}^{-1}$ range (Figure $8 \mathrm{c}$ ), after [R5b], a $\mathrm{C}=\mathrm{O}$ band is observed at $1695 \mathrm{~cm}^{-1}$ (Figure $8 \mathrm{~b}$ ) at the same position as for $\mathrm{Au}-$ $\left(\mathrm{CH}_{2}\right)_{4}-\mathrm{COOH}$ (Figure 8a) albeit with an absorbance that is $63 \%$ lower. In the XPS spectrum, starting from $\mathrm{Au}-\mathrm{S}-$ 


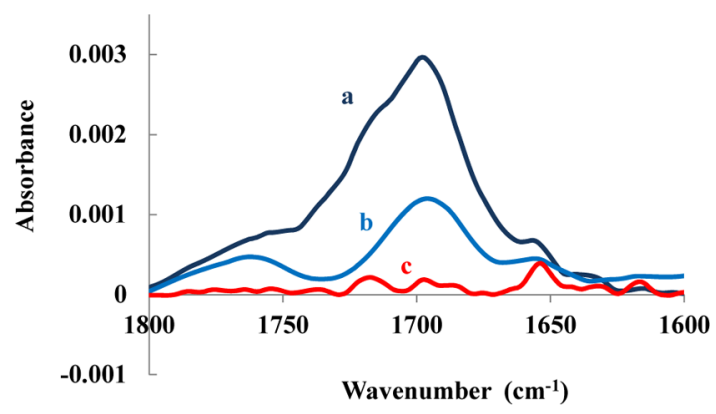

Figure 8. IRRAS spectra of (a) $\mathrm{Au}-\left(\mathrm{CH}_{2}\right)_{4}-\mathrm{COOH}$, (b) $\mathrm{Au}-\mathrm{S}-$ $\left(\mathrm{CH}_{2}\right)_{17}-\mathrm{CH}_{3}$ exchanged by $-\left(\mathrm{CH}_{2}\right)_{4}-\mathrm{COOH}$ groups by electrochemistry [R5b], and (c) $\mathrm{Au}-\mathrm{S}-\left(\mathrm{CH}_{2}\right)_{17}-\mathrm{CH}_{3}$.

$\left(\mathrm{CH}_{2}\right)_{17}-\mathrm{CH}_{3}$ with $\mathrm{S} / \mathrm{Au}=0.09$, after [R5b], S/Au $=0.07$ and the $\mathrm{C} 1 \mathrm{~s}$ peak presents two very small contributions (at 286.5 and $288.8 \mathrm{eV}$ ) corresponding to the carboxylic group of $\mathrm{Au}-$ $\left(\mathrm{CH}_{2}\right)_{4}-\mathrm{COOH}$. The water contact angle changes from $\theta=$ $107 \pm 0.8$ to $96.8 \pm 1.0^{\circ}$, indicating that thiol groups are still present on the surface in agreement with the IR spectrum. This experiment demonstrates that reaction [R5] is possible in the two directions but the direct reaction $([\mathrm{R} 5 \mathrm{f}])$ is much more efficient than the reverse one $([\mathrm{R} 5 \mathrm{~b}])$. In addition, it is possible that part of the $\mathrm{C}=\mathrm{O}$ groups observed after [R5b] correspond to valeric groups attached to the $\mathrm{C}_{18}$ alkyl chain of the thiol owing to a $\mathrm{H}$-atom abstraction from the $\mathrm{C}_{18}$ alkyl chain of the thiol by the valeric radical $\left(\mathrm{R}^{\bullet}\right.$ in reaction [R3]) followed by the coupling of another $\mathrm{R}^{\bullet}$ with the $\mathrm{CH}^{\bullet}$ radical formed on the $\mathrm{C}_{18}$ alkyl chain.

The exchange between $\mathrm{Au}-\left(\mathrm{CH}_{2}\right)_{4}-\mathrm{COOH}$ and $\mathrm{SH}-$ $\left(\mathrm{CH}_{2}\right)_{5}-\mathrm{COOH}([\mathrm{R} 6 \mathrm{f}])$, the structures of which are closely related, was also tested. The comparison of the IR spectra and water contact angles of $\mathrm{Au}-\left(\mathrm{CH}_{2}\right)_{4}-\mathrm{COOH}$ and $\mathrm{Au}-\mathrm{S}-$ $\left(\mathrm{CH}_{2}\right)_{5}-\mathrm{COOH}\left(\theta=58 \pm 0.8^{\circ}\right)$ is not informative because the two grafted surfaces are too similar. However, the XPS spectrum of $\mathrm{Au}-\left(\mathrm{CH}_{2}\right)_{4}-\mathrm{COOH}$ and that of $\mathrm{Au}-\mathrm{S}-$ $\left(\mathrm{CH}_{2}\right)_{5}-\mathrm{COOH}$ present a $\mathrm{S} 2 \mathrm{p}$ contribution of respectively 0 and $3 \%(\mathrm{~S} / \mathrm{Au}=0.06$ in the latter $)$. The XPS spectrum recorded after $[\mathrm{R} 6 \mathrm{f}]$ indicates $\mathrm{S} / \mathrm{Au}=0.06$ testifying for the exchange reaction. Conversely starting from $\mathrm{Au}-\mathrm{S}-\left(\mathrm{CH}_{2}\right)_{5}-$ $\mathrm{COOH}$, after electrografting of bromovaleric acid ([R6b] as in the experimental section) $\mathrm{S} / \mathrm{Au}=0.04$.

$$
\begin{aligned}
& \mathrm{Au}-\left(\mathrm{CH}_{2}\right)_{4}-\mathrm{COOH}+\mathrm{SH}-\left(\mathrm{CH}_{2}\right)_{5}-\mathrm{COOH} \\
& \underset{\mathrm{R} 6 \mathrm{~b}}{\mathrm{R} 6 \mathrm{f}} \mathrm{Au}-\mathrm{S}-\left(\mathrm{CH}_{2}\right)_{5}-\mathrm{COOH}+\mathrm{CH}_{3}-\left(\mathrm{CH}_{2}\right)_{3}-\mathrm{COOH}
\end{aligned}
$$

Exchange reactions R5 and R6 are possible in both directions (with the restriction above concerning the reverse reaction). Note that these reactions are more complex than a simple exchange on a gold surface because a hydrogen atom is also exchanged in the process. Concerning reactions $[\mathrm{R} 5 \mathrm{~b}]$ and [R6b], thiols on gold are electrochemically desorbed in $0.5 \mathrm{M}$ $\mathrm{KOH}$ after transfer of one electron at $E \approx-1.2 /-1.4 \mathrm{~V} / \mathrm{SCE}$ to give thiolates. Because we operate at much lower potentials and in the presence of valeric radicals, the mechanism is likely different.

\section{CONCLUSIONS}

Both theoretical and experimental results indicate that during the electrografting of bromovaleric acid onto $\mathrm{Au}$ to give $\mathrm{Au}-$
$\left(\mathrm{CH}_{2}\right)_{4}-\mathrm{COOH}$ : (i) a covalent bond is formed between the gold surface and the organic group (observed by Raman SERS spectroscopy at $387 \mathrm{~cm}^{-1}$ and identical to the calculated value), (ii) the radical character of this reaction leads to multilayered films as previously observed with diazonium salts and amines, ${ }^{10-12}$ (iii) the energy of the $\mathrm{Au}-\mathrm{C}$ (alkyl) bond is $\sim-37 \mathrm{kcal} / \mathrm{mol}$ (less stable than that of the $\mathrm{Au}-\mathrm{S}$ bond of a thiol SAM by $8.6 \mathrm{kcal}$ ), and (iv) based on these similar bonding energies, we have shown experimentally that $\mathrm{Au}-$ $\left(\mathrm{CH}_{2}\right)_{4}-\mathrm{COOH}$ can be transformed reversibly into $\mathrm{Au}-\mathrm{S}-$ $\left(\mathrm{CH}_{2}\right)_{17}-\mathrm{CH}_{3}$ or $\mathrm{Au}-\mathrm{S}-\left(\mathrm{CH}_{2}\right)_{5}-\mathrm{COOH}$ in the presence of the corresponding thiol.

\section{ASSOCIATED CONTENT}

\section{Supporting Information}

The Supporting Information is available free of charge on the ACS Publications website at DOI: 10.1021/acs.langmuir.8b01584.

Simulated Raman spectrum of $\mathrm{Au}$ and $\mathrm{Au}-\mathrm{CH}_{2}-$ $\left(\mathrm{CH}_{2}\right)_{3}-\mathrm{COOH}$; different binding sites onto $\mathrm{Au}(111)$ surface; and comparison of $\mathrm{Au}-\mathrm{S}-\left(\mathrm{CH}_{2}\right)_{17}-\mathrm{CH}_{3}$ obtained directly and by exchange of $\mathrm{Au}-\left(\mathrm{CH}_{2}\right)_{4}-$ $\mathrm{COOH}$ via IRRAS and XPS spectra (PDF)

\section{AUTHOR INFORMATION}

\section{Corresponding Authors}

*E-mail: avniberisha83@gmail.com (A.B.).

*E-mail: jean.pinson@univ-paris-diderot.fr (J.P.).

ORCID

Frédéric Kanoufi: 0000-0002-9784-2380

Claire Mangeney: 0000-0002-9817-3262

François Maurel: 0000-0002-4768-1902

Jean Pinson: 0000-0001-6176-8636

\section{Notes}

The authors declare no competing financial interest.

\section{ACKNOWLEDGMENTS}

CNRS, Paris Diderot University, and ANR (Agence Nationale de la Recherche) and CGI (Commissariat à l'Investissement d'Avenir) are gratefully acknowledged for their financial support of this work through Labex SEAM (Science and Engineering for Advanced Materials and devices) ANR 11 LABX 086, ANR 11 IDEX 0502.

\section{REFERENCES}

(1) Pujari, S. P.; Scheres, L.; Marcelis, A. T. M.; Zuilhof, H. Covalent surface modification of oxide surfaces. Angew. Chem., Int. Ed. 2014, $53,6322-6356$.

(2) Zharov, I.; Khabibullin, A. Surface-Modified Silica Colloidal Crystals: Nanoporous Films and Membranes with Controlled Ionic and Molecular Transport. Acc. Chem. Res. 2014, 47, 440-449.

(3) Wasserman, S. R.; Tao, Y. T.; Whitesides, G. M. Structure and reactivity of alkylsiloxane monolayers formed by reaction of alkyltrichlorosilanes on silicon substrates. Langmuir 1989, 5, 10741087.

(4) Queffélec, C.; Petit, M.; Janvier, P.; Knight, D. A.; Bujoli, B. Surface modification using phosphonic acids and esters. Chem. Rev. 2012, 112, 3777-3807.

(5) Guerrero, G.; Alauzun, J. G.; Granier, M.; Laurencin, D.; Mutin, P. H. Phosphonate coupling molecules for the control of surface/ interface properties and the synthesis of nanomaterials. Dalton Trans. 2013, 42, 12569-12585. 
(6) Schwarz, M.; Mohr, S.; Xu, T.; Döpper, T.; Weiß, C.; Civale, K.; Hirsch, A.; Görling, A.; Libuda, J. Anchoring of a CarboxylFunctionalized Norbornadiene Derivative to an Atomically Defined Cobalt Oxide Surface. J. Phys. Chem. C 2017, 121, 11508-11518.

(7) Fabre, B.; Pujari, S. P.; Scheres, L.; Zuilhof, H. Micropatterned ferrocenyl monolayers covalently bound to hydrogen-terminated silicon surfaces: effects of pattern size on the cyclic voltammetry and capacitance characteristics. Langmuir 2014, 30, 7235-7243.

(8) Fairman, C.; Chockalingam, M.; Liu, G.; Soeriyadi, A. H.; Gooding, J. J. Light-induced organic monolayer modification of iodinated carbon electrodes. Langmuir 2014, 30, 332-339.

(9) Pensa, E.; Cortés, E.; Corthey, G.; Carro, P.; Vericat, C.; Fonticelli, M. H.; Benítez, G.; Rubert, A. A.; Salvarezza, R. C. The Chemistry of the Sulfur-Gold Interface: In Search of a Unified Model. Acc. Chem. Res. 2012, 45, 1183-1192.

(10) Aryl diazonium Salts. In New Coupling Agents in Polymer and Surface Science; Chehimi, M. M., Ed.; Wiley-VCH: Weinheim, 2012.

(11) Bélanger, D.; Pinson, J. Electrografting: a powerful method for surface modification. Chem. Soc. Rev. 2011, 40, 3995-4048.

(12) Berisha, A.; Combellas, C.; Kanoufi, F.; Decorse, P.; Oturan, N.; Médard, J.; Seydou, M.; Maurel, F.; Pinson, J. Some theoretical and experimental insights on the mechanistic routes leading to the spontaneous grafting of gold surfaces by diazonium salts. Langmuir 2017, 33, 8730-8738.

(13) Palacin, S.; Bureau, C.; Charlier, J.; Deniau, G.; Mouanda, B.; Viel, P. Molecule-to-metal bonds: electrografting polymers on conducting surfaces. ChemPhysChem 2004, 5, 1468-1481.

(14) Laurentius, L.; Stoyanov, S. R.; Gusarov, S.; Kovalenko, A.; Du, R.; Lopinski, G. P.; McDermott, M. T. Diazonium-Derived Aryl Films on Gold Nanoparticles: Evidence for a Carbon-Gold Covalent Bond. ACS Nano 2011, 5, 4219-4227.

(15) Galicia, M.; González-Fuentes, M. A.; Valencia, D. P.; González, F. J. The effect of substituents on the anodic oxidation of aliphatic carboxylates and the passage towards a pseudo-Kolbe reaction. J. Electroanal. Chem. 2012, 672, 28-33.

(16) Fellah, S.; Amiar, A.; Ozanam, F.; Chazalviel, J.-N.; Vigneron, J.; Etcheberry, A.; Stchakovsky, M. Grafting and Polymer Formation on Silicon from Unsaturated Grignards: II. Aliphatic Precursors. J. Phys. Chem. B 2007, 111, 1310-1317.

(17) Chehimi, M. M.; Hallais, G.; Matrab, T.; Pinson, J.; Podvorica, F. I. Electro- and Photografting of Carbon or Metal Surfaces by Alkyl Groups. J. Phys. Chem. C 2008, 112, 18559-18565.

(18) Hetemi, D.; Kanoufi, F.; Combellas, C.; Pinson, J.; Podvorica, F. I. Electrografting of Alkyl Films at Low Driving Force by Diverting the Reactivity of Aryl Radicals Derived from Diazonium Salts. Langmuir 2014, 30, 13907-13913.

(19) Hetemi, D.; Médard, J.; Decorse, P.; Combellas, C.; Kanoufi, F.; Pinson, J.; Podvorica, F. I. Surface Functionalization of Metals by Alkyl Chains through a Radical Crossover Reaction. Langmuir 2016, $32,6335-6342$.

(20) Hetemi, D.; Hazimeh, H.; Decorse, P.; Galtayries, A.; Combellas, C.; Kanoufi, F.; Pinson, J.; Podvorica, F. I. One-Step Formation of Bifunctionnal Aryl/Alkyl Grafted Films on Conducting Surfaces by the Reduction of Diazonium Salts in the Presence of Alkyl Iodides. Langmuir 2015, 31, 5406-5415.

(21) Hetemi, D.; Médard, J.; Kanoufi, F.; Combellas, C.; Pinson, J.; Podvorica, F. I. Surface Modification of Polymers by Reaction of Alkyl Radicals. Langmuir 2016, 32, 512-518.

(22) Tang, Q.; Jiang, D.-e. Computational Insight into the Covalent Organic-Inorganic Interface. Chem. Mater. 2016, 28, 5976-5988.

(23) Jiang, D.-e.; Sumpter, B. G.; Dai, S. Structure and Bonding between an Aryl Group and Metal Surfaces. J. Am. Chem. Soc. 2006, 128, 6030-6031.

(24) de la Llave, E.; Ricci, A.; Calvo, E. J.; Scherlis, D. A. Binding between Carbon and the $\mathrm{Au}(111)$ Surface and What Makes It Different from the S-Au(111) Bond. J. Phys. Chem. C 2008, 112, 17611-17617.
(25) Huang, P.; Jing, L.; Zhu, H.; Gao, X. Diazonium Functionalized Graphene: Microstructure, Electric, and Magnetic Properties. Acc. Chem. Res. 2012, 46, 43-52.

(26) Boukerma, K.; Chehimi, M. M.; Pinson, J.; Blomfield, C. X-ray Photoelectron Spectroscopy Evidence for the Covalent Bond between an Iron Surface and Aryl Groups Attached by the Electrochemical Reduction of Diazonium Salts. Langmuir 2003, 19, 6333-6335.

(27) Bell, K. J.; Brooksby, P. A.; Polson, M. I. J.; Downard, A. J. Evidence for covalent bonding of aryl groups to $\mathrm{MnO}_{2}$ nanorods from diazonium-based grafting. Chem. Commun. 2014, 50, 13687-13690.

(28) Mesnage, A.; Esnouf, S.; Jégou, P.; Deniau, G.; Palacin, S. Understanding the redox-induced polymer grafting process: A dual surface-solution analysis. Chem. Mater. 2010, 22, 6229-6239.

(29) Combellas, C.; Kanoufi, F.; Pinson, J.; Podvorica, F. I. Time-ofFlight Secondary Ion Mass Spectroscopy Characterization of the Covalent Bonding between a Carbon Surface and Aryl Groups. Langmuir 2005, 21, 280-286.

(30) Brymora, K.; Fouineau, J.; Eddarir, A.; Chau, F.; Yaacoub, N.; Grenèche, J.-M.; Pinson, J.; Ammar, S.; Calvayrac, F. Grafting of diazonium salts on oxides surface: formation of aryl-O bonds on iron oxide nanoparticles. J. Nanopart. Res. 2015, 17, 438.

(31) Jiang, D.-e.; Sumpter, B. G.; Dai, S. How Do Aryl Groups Attach to a Graphene Sheet? J. Phys. Chem. B 2006, 110, 2362823632.

(32) Berisha, A.; Combellas, C.; Kanoufi, F.; Pinson, J.; Ustaze, S.; Podvorica, F. I. Indirect Grafting of Acetonitrile-Derived Films on Metallic Substrates. Chem. Mater. 2010, 22, 2962-2969.

(33) Frisch, M. J.; Trucks, G. W.; Schlegel, H. B.; Scuseria, G. E.; Robb, M. A.; Cheeseman, J. R.; Scalmani, G.; Barone, V.; Petersson, G. A.; Nakatsuji, H.; Li, X.; Caricato, M.; Marenich, A.; Bloino, J.; Janesko, B. G.; Gomperts, R.; Mennucci, B.; Hratchian, H. P.; Ortiz, J. V.; Izmaylov, A. F.; Sonnenberg, J. L.; Williams-Young, D.; Ding, F.; Lipparini, F.; Egidi, F.; Goings, J.; Peng, B.; Petrone, A.; Henderson, T.; Ranasinghe, D.; Zakrzewski, V. G.; Gao, J.; Rega, N.; Zheng, G.; Liang, W.; Hada, M.; Ehara, M.; Toyota, K.; Fukuda, R.; Hasegawa, J.; Ishida, M.; Nakajima, T.; Honda, Y.; Kitao, O.; Nakai, H.; Vreven, T.; Throssell, K.; Montgomery, J. A., Jr.; Peralta, J. E.; Ogliaro, F.; Bearpark, M.; Heyd, J. J.; Brothers, E.; Kudin, K. N.; Staroverov, V. N.; Keith, T.; Kobayashi, R.; Normand, J.; Raghavachari, K.; Rendell, A.; Burant, J. C.; Iyengar, S. S.; Tomasi, J.; Cossi, M.; Millam, J. M.; Klene, M.; Adamo, C.; Cammi, R.; Ochterski, J. W.; Martin, R. L.; Morokuma, K.; Farkas, O.; Foresman, J. B.; Fox, D. J. Gaussian 09, Revision A.02; Gaussian, Inc.: Wallingford CT, 2016.

(34) Ahmad, R.; Félidj, N.; Boubekeur-Lecaque, L.; Lau-Truong, S.; Gam-Derouich, S.; Decorse, P.; Lamouri, A.; Mangeney, C. Watersoluble plasmonic nanosensors with synthetic receptors for label-free detection of folic acid. Chem. Commun. 2015, 51, 9678-9681. and references therein

(35) Perdew, J. P.; Burke, K.; Ernzerhof, M. Generalized gradient approximation made simple. Phys. Rev. Lett. 1996, 77, 3865-3868; erratum. Phys. Rev. Lett. 1997, 78, 1396.

(36) Perdew, J. P.; Chevary, J. A.; Vosko, S. H.; Jackson, K. A.; Pederson, M. R.; Singh, D. J.; Fiolhais, C. Atoms, Molecules, Solids, and Surfaces: Applications of the Generalized Gradient Approximation for Exchange and Correlation. Phys. Rev. B: Condens. Matter Mater. Phys. 1992, 46, 6671-6687.

(37) Kresse, G.; Hafner, J. Ab initio molecular dynamics for liquid metals. Phys. Rev. B: Condens. Matter Mater. Phys. 1993, 47, 558-561.

(38) Kresse, G.; Joubert, D. From Ultrasoft Pseudopotentials to the Projector Augmented-Wave Method. Phys. Rev. B: Condens. Matter Mater. Phys. 1999, 59, 1758-1775.

(39) Jamróz, M. H. Vibrational Energy Distribution Analysis (VEDA): Scopes and limitations. Spectrochim. Acta, Part A 2013, $114,220-230$.

(40) Varnholt, B.; Oulevey, P.; Luber, S.; Kumara, C.; Dass, A.; Bürgi, T. Structural Information on the Au-S Interface of ThiolateProtected Gold Clusters: A Raman Spectroscopy Study. J. Phys. Chem. C 2014, 118, 9604-9611. 
(41) Nassoko, D.; Seydou, M.; Goldmann, C.; Chanéac, C.; Sanchez, C.; Portehault, D.; Tielens, F. Rationalizing the formation of binary mixed thiol self-assembled monolayers. Mater Today Chem. 2017, 5, 34-42.

(42) Lassoued, K.; Seydou, M.; Raouafi, F.; Larbi, F.; Lang, P.; Diawara, B. DFT study of the adsorption and dissociation of 5hydroxy-3-butanedithiol-1,4-naphthaquinone (Jug-C4-thiol) on $\mathrm{Au}(111)$ surface. Adsorption 2018, 24, 191-201.

(43) Häkkinen, $\mathrm{H}$. The gold-sulfur interface at the nanoscale. Nat. Chem. 2012, 4, 443-455.

(44) Jadzinsky, P. D.; Calero, G.; Ackerson, C. J.; Bushnell, D. A.; Kornberg, R. D. Structure of a Thiol Monolayer-Protected Gold Nanoparticle at 1.1 A Resolution. Science 2007, 318, 430-433.

(45) Shewchuk, D. M.; McDermott, M. T. Comparison of Diazonium Salt Derived and Thiol Derived Nitrobenzene Layers on Gold. Langmuir 2009, 25, 4556-4563.

(46) Bain, C. D.; Whitesides, G. M. Formation of Monolayers by the Coadsorption of Thiols on Gold: Variation in the Length of the Alkyl Chain. J. Am. Chem. Soc. 1989, 111, 7164-7175.

(47) National Institute of Advanced Industrial Science and Technology. http://sdbs.db.aist.go.jp last (accessed May 2, 2017).

(48) Yeon, H.; Wang, C.; Van Lehn, R. C.; Abbott, N. L. Influence of Order within Nonpolar Monolayers on Hydrophobic Interactions. Langmuir 2017, 33, 4628-4637.

(49) Tsuneda, S.; Ishida, T.; Nishida, N.; Hara, M.; Sasabe, H.; Knoll, W. Tailoring of a smooth polycrystalline gold surface as a suitable anchoring site for a self-assembled monolayer. Thin Solid Films 1999, 339, 142-147. 